\title{
RENEGOTIATION OF METROPOLITAN HERITAGE IN CHINA: YIHE MANSIONS, NANJING
}

\author{
SUXIN ZHANG ${ }^{1}$, GERHARDES JOHANNES BEUKES BRUYNS ${ }^{1}$, \\ TIMOTHY JOSEPH JACHNA ${ }^{2} \&$ YUANHONG MA $^{3}$ \\ ${ }^{1}$ School of Design, The Hong Kong Polytechnic University, Hong Kong \\ ${ }^{2}$ College of Design, Architecture, Art and Planning, University of Cincinnati, USA \\ ${ }^{3}$ School of Architecture, Harbin Institute of Technology, China
}

\begin{abstract}
The Chinese economic reform and opening during the 1980s (改革開放) is not only credited for China's modernisation - through accelerated urbanisation and its social and economic legislation - it is also acknowledged for the establishment of heritage legislation to protect Chinese cultural capital. In contrast, the consequences of these reforms are concomitantly blamed for the current imbalance between urban development and heritage protection that in the current reality favours economic growth over heritage policies. With heritage awareness on the rise, the recent government-led projects have spearheaded new directions, merging neoliberal planning and heritage protection in regeneration projects. This paper will discuss the Yihe Mansions project (頣和公館), Nanjing, a regeneration project earmarked as a residential area for senior officials in the Republic of China. As one of four cases of a research programme, the Yihe Mansions case will illustrate the application of a developmental model, exploring the intricate balance between economic development, protection and contemporary lifestyles in inner urban areas. This paper also deliberates a new dialogue between decision makers and end users under the public ownership of land, exploring how the government integrates the public's wishes as part of state-driven real estate projects. Applying unobtrusive and obtrusive research methodologies, this paper is grounded in a more holistic understanding of the renegotiation of Chinese metropolitan areas between development and protection that aims to establish a dynamic and feasible model of heritage protection in Chinese urban settings.

Keywords: Chinese metropolitan heritage areas, Yihe Mansions, the balance between urban development and heritage protection, the renegotiation between decision makers and end users.
\end{abstract}

\section{INTRODUCTION}

"China Booms", a frequently mentioned phrase in the last years [1], expresses the explosive growth and unprecedented changes in China caused by the Chinese economic reform and opening (改革開放) since the 1980s. China's transition from planned to market economy triggers a set of tipping transformation in society, namely marketisation, decentralisation, industrialisation, migration, and globalisation [2]. The subsequent consequences in China's cities are a dizzying pace of urbanisation, aggressive urban sprawl and dramatic changes in urban life [2]. The World Bank released the statistic of China's urbanisation level which increased from $19.4 \%$ in 1980 to $57.9 \%$ in 2017 . The massive new urban immigrants from rural areas promote the local economy, but it is also stressful on demands of urban infrastructure, housing and workplace. Therefore, the land values in urban areas dramatically increased, especially in the centre of Chinese metropolises with an integrated infrastructure system of education and medical health. For example, the average prices of commercial housing in Nanjing increased from around $\$ 810 / \mathrm{m}^{2}$ in 2007 to $2800 / \mathrm{m}^{2}$ in 2016 .

In the 1980s, the central government intensively established a modern system of heritage protection to rescue precious heritage that survived from the chaotic years of the Maoist period [3]. Specifically, the central government released the first heritage legislation and the first list of historic cities in 1982 [3]-[6]. These are seen as a symbol of the transformation of the government concentration on heritage protection from monuments and cultural relics 
to heritage sites and areas [7], [8]. The quantity and quality of heritage conservation areas are one of the fundamental attributes in the Chinese city, to determine whether it is listed as a historic city. Generally, the majority of heritage conservation areas are located at the centre of Chinese cities due to urban settlement and development, like the imperial city of Beijing, Pingjiang Road of Suzhou and FAW Factory of Changchun. Therefore, the heritage protection of existing heritage conservation areas located in the centres of Chinese metropolises faces huge challenges from the temptation of soaring land values and demands of the modern lifestyle. In order to maximise benefits and meet the demands of modern lifestyle in a short time, the majority of the local government advocates that the regeneration projects of heritage conservation areas are either inhabitants' relocation to create "theme parks" for the gentrification or reconstruction of historic urban landscape to create "fake antiques" for the tourism [7]. As a large number of Chinese metropolises are developing at an unprecedented rate, the conflict between heritage protection and urban development will still be faced in the future.

\section{ADAPTIVE MODEL IN CHINESE METROPOLITAN HERITAGE AREAS}

Placemaking, a trendy concept of urban design, tends to form relationships between people and between people and their places based on the multi-stakeholder collaboration [9], [10], ultimately improving the quality of physical conditions of the places and making a sense of place for the compact community [11], [12]. Placemaking is a potential concept to be used in the regeneration projects of heritage conservation areas, even though it is a key point on public space projects.

The first reason is that a heritage conservation area can be seen as a unique place. In terms of the definition, "place" is outlined by the physical and social boundaries to support human activities and experience[13]-[15], while the heritage conservation area delimited by the government reflects the special physical environment and the local cultural context [16]-[18]. Secondly, there is a high relevance between placemaking and heritage protection in principles and aims. Particularly, ICOMOS China [19] determined seven principles for the conservation of heritage site in China, namely (i) historic condition, (ii) authenticity, (iii) integrity, (iv) minimal intervention, (v) cultural traditions, (vi) appropriate technology and (vii) disaster preparedness.

Heritage protection should be seen as a dynamic process to realise cultural significances and economic values of heritage [20] under the Chinese heritage legislation. Based on studies of international scholars and practitioners, the set of principles of placemaking can be summarised, namely (i) compact communities, (ii) ICON, (iii) potential for redevelopment, (iv) integration of housing and employment, (v) neighbourhoods, (vi) aesthetic appeal, (vii) mixed classes of households, (viii) walkability and public, (ix) transportation, (x) environmental resource, (xi) historic and cultural resource, (xii) identity, (xiii) sense of place, (xiv) public realm, (xv) implementation [21]-[25]. As illustrated in the relationship matrix of their principles (see Fig. 1), there are 111 options filled in "relationships" (a total of 154), which means heritage protection and placemaking are highly related to each other. Additionally, this matrix shows that the top three principles reflecting the high relevancy between placemaking and heritage protection fall under ICON, identity, historic and cultural resource in placemaking as well as a dynamic process, cultural and development significance in heritage protection, which means sustainable development and local characteristics are vital principles of two concepts. Moreover, the goals of heritage protection are not only to subject to the qualification of heritage as the premises, but also to show a series of outstanding universal values [26] and meet the demands of social-economic development [27], [28]. The criteria of Chinese heritage protection claim the following, namely authenticity, integrity, 
identity, historical values, aesthetic values, social values, scientific values, cultural values and functional values [19]. In parallel, according to the specialists' studies and practice, a set of criteria of placemaking can be built up including a sense of place, sense of neighbourhood, identity, public health/healthy living, aesthetic appeal, community, public space mixed-use and activities, economic opportunities, ecological diversity and nature, social capital/ government support, implementation [15], [23], [25], [29]. Showing in Fig. 2, there are 86 options filled in "relationships" (a total of 120) and the positive correlation between criteria of placemaking and heritage protection occupies around $89.5 \%$ of all relationships. It means that placemaking and heritage protection, two different urban design concepts, reach consensus in their goals.

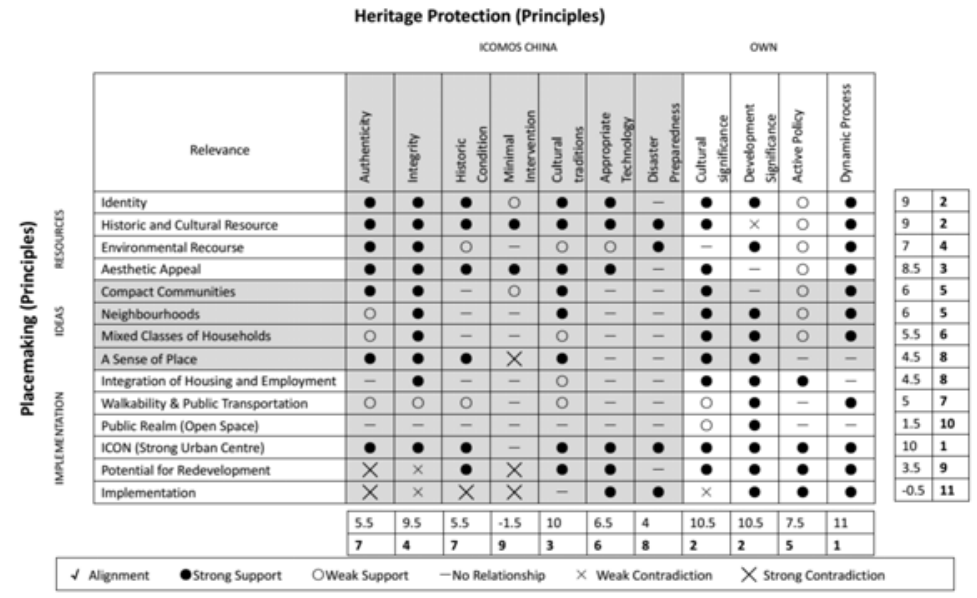

Figure 1: Matrix of relationships between heritage protection and placemaking in principles. (Source: Author.)

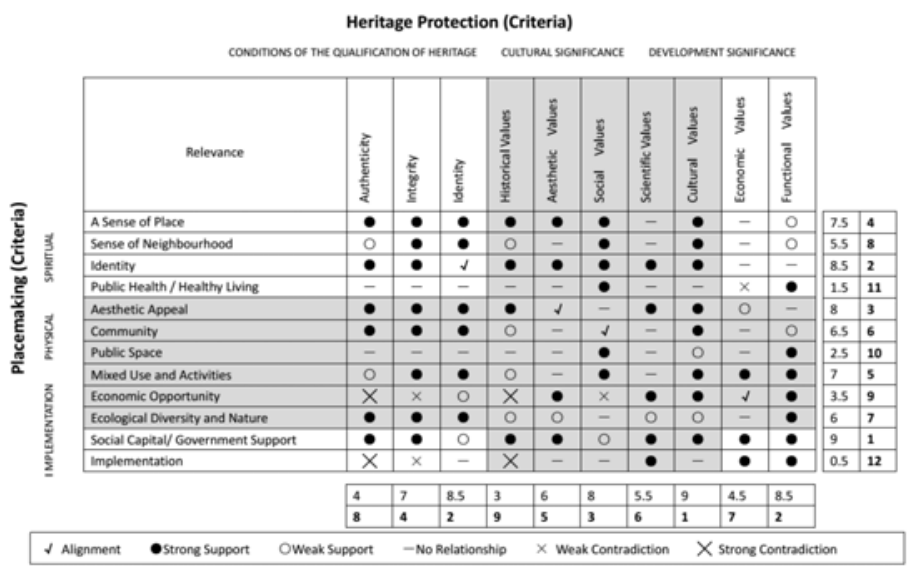

Figure 2: Matrix of relationships between heritage protection and placemaking in criteria. (Source: Author.) 
In conclusion, the heritage conservation area as a kind of place, can adopt placemaking to realise a coherent and dynamic development of the "loci", ultimately reaching consensuses between development and protection as there is the high relevance between placemaking and heritage protection in the principles and aims. As certified by Project for Public Space [30] placemaking helps a heritage conservation area to restore its historically social function, to embody the creation by the community and to expand the impact of heritage protection projects. Additionally, under the public land ownership in China, the government and social support are vital to the regeneration of the heritage conservation area. In brief, placemaking, as a potential conceptual model can be applied to the regeneration model of a heritage conservation area to alleviate the conflict between urban development and heritage protection.

\section{APPLICATION OF THE MODEL: YIHE MASION BLOCK}

\subsection{History of Yihe Mansions and its significance}

Nanjing is the capital of Jiangsu province and it served as the capital of the Republic of China, securing an important hub of education, economics, culture and politics in China. The central government in the Republic of China released "The City Plan of Nanking” in 1929 which is the first modern urban planning in China. This planning proposed Yihe Area to be transformed from nature park to a residential area that served senior bureaucrats and foreign ambassadors. In 1984, Yihe Area was listed as one of 12 heritage conservation areas in Nanjing. Due to the accelerated urban sprawl, the Yihe conservation area has been a central part of Nanjing, showing in Fig. 3.

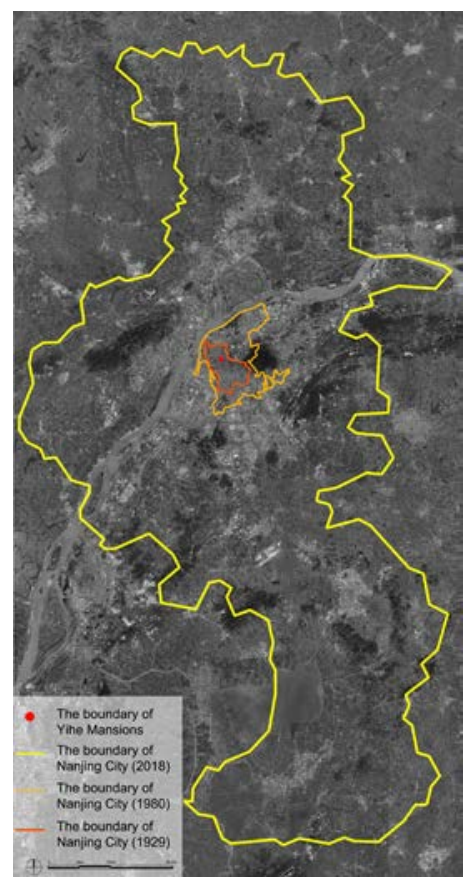

Figure 3: The boundaries of Nanjing in different periods. (Source: Author.) 
Yihe heritage conservation area is the most well-preserved residential area with luxury houses of the Republic of China. This area not only reflects the fusion of Chinese and Western cultures during that special period by buildings and streetscapes, but also contains profound and significant historic values as it served for the senior officials of the Republic of China.

Yihe Mansions, called the 12th block of the Yihe conservation area, is located in the eastern portion of this heritage conservation area and is adjacent to a commercial and office cluster. The local government holds the majority of land ownership of this block [31]. In Yihe Mansions, the buildings were allowed to adopt different approaches for their protection and development according to conditions and significances of each building. Thus, Yihe Mansions as a pilot project was redeveloped in 2014 and then it was awarded the Honourable Mention of UNESCO Asia-Pacific Cultural Heritage Conservation.

\subsection{Urban regeneration project: Government-led redevelopment and protection project}

After the establishment of the People's Republic of China, the residents were workers and officials instead of senior bureaucrats and foreign ambassadors. Due to the lack of routine maintenance, most buildings in Yihe Mansions failed to meet the demands of modern lifestyle and urban development. In order to improve the run-down housing and release the land values, the municipal government forced residents' relocation and then appointed the Nanjing Urban Planning Bureau to implement the regeneration project of Yihe Mansions block in 2013 (see Fig. 4). Particularly, it proposed the refurbishment of historical elements including the landscapes and constructions for conservation of the historic environment of "Republic of China"; the adaptive reuse of 26 important houses transformed from the residential to a themes hotel; the appropriate construction of new buildings in harmony with the local historical environment to meet the needs of a theme hotel; and the optimisation of the local infrastructure and functions to improve the quality of this block [31]. From the above, the regeneration project of Yihe Mansions adopts 7 of 10 heritage protection principles and 9 of 14 placemaking principles (see Fig. 5). Additionally, this regeneration project was invested by the municipal government, designed by the local planning department and then has been managed by a state-owned enterprise.

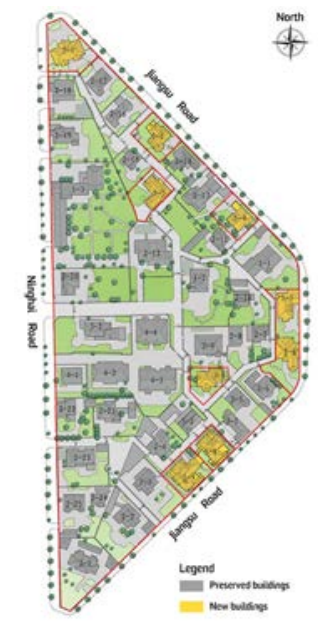

Figure 4: The master plan of Yihe Mansions. (Source: Nanjing Urban Planning Bureau.) 


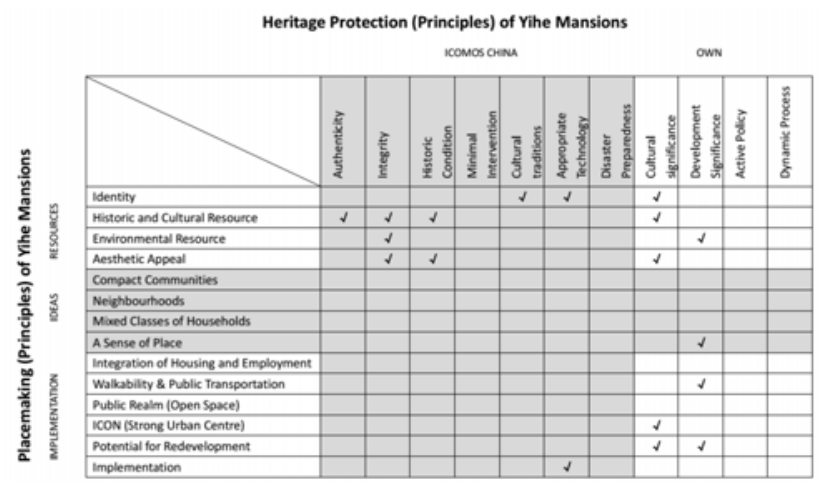

Figure 5: The principles matrix of Yihe Mansions Block. (Source: Author.)

\section{DISCUSSION OF THE APPLIED MODEL}

This study evaluates this adaptive model applied to the regeneration project of Yihe Mansions in terms of physical conditions and individual perception by archival research, observation and questionnaire, to discuss the balance between development, protection and contemporary lifestyle. The reason is that the values and qualification of heritage conservation area not only reflect in the visible environment such as streetscape and buildings but also reflect in the invisible attributes such as identity.

\subsection{Physical conditions}

In terms of urban morphology, it is instructive to note that the urban pattern of the Yihe heritage conservation area has been largely retained after the completion of the regeneration project of Yihe Mansions area, even though some fragmented buildings had been integrated to optimise the buildings' space (see Fig. 6). According to the field observation, the harmony of both the Yihe Mansions and its surroundings reflecting in the landscape and buildings creates the unique ambience of the Republic of China. Meanwhile, the high-quality environment of this area provides a place to support social activities and daily exercise of the community. Specifically, many old peoples take care of their grandchildren to play with the other children at two sites in the Yihe Mansions, which are unselfconsciously shaped as two public spaces by the community's activities. The elderly who do not need to take care of their grandchildren always either chat with others at these two sites or stroll through this area (see Fig. 7).

In terms of building typology, most historical buildings have been conserved and improved while new buildings have been in accord with the style of existing historical buildings. The existing historical buildings have been adaptively reused to transform their function from the residential to the commercial but have conserved the typology of the luxury houses as they are fundamental components and characteristics of the theme hotel. Moreover, the hotel provides six important celebrity homes for exhibition, showing the life of historic figures who had lived here. It not only provides public facilities for the neighbourhoods but also narrates the local culture and history. Therefore, in terms of physical conditions, this project not only improves the quality of environment. It also protects the historical buildings by infilling new functions, whilst bringing the economic returns to the government and offers new infrastructure to meet the needs of the contemporary life of the community. 

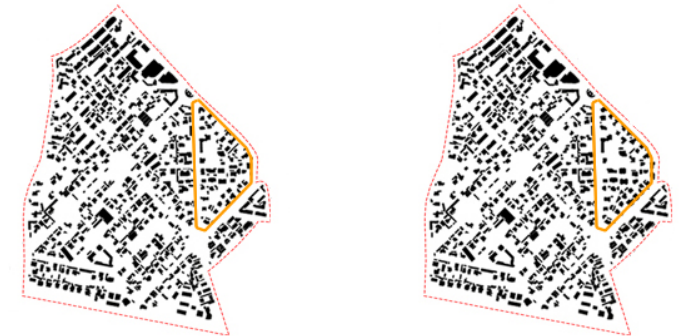

YIHE HERITAGE CONSERVATION AREA, NANJING

(35.19 ha)

$\oplus$

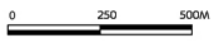

Figure 6: Figure ground of Yihe Heritage Conservation Area before and after the redevelopment. (Source: Author.)

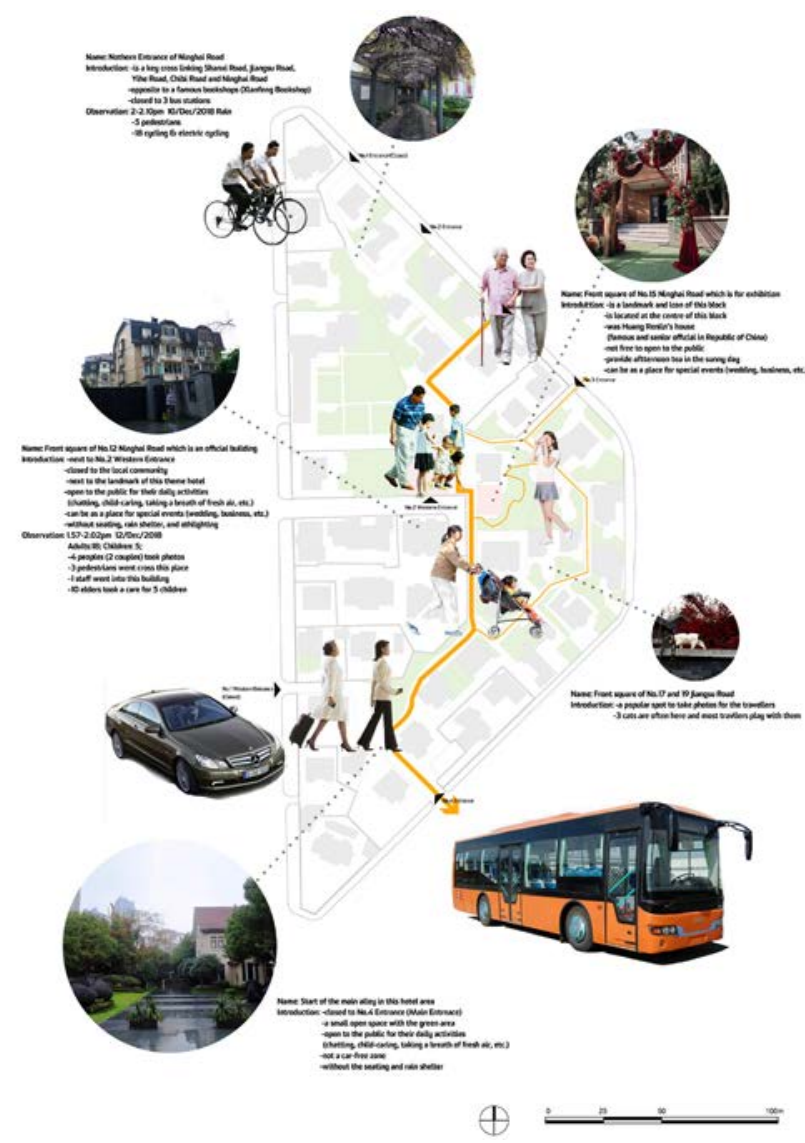

Figure 7: Pedestrian movement and activities in Yihe Mansions. (Source: Author.) 


\subsection{End-users’ perception}

End-users, the community and tourists, can directly evaluate the development and protection of Yihe Mansions through their immediate experience. There are 32 respondents participating in this study through the questionnaire. After the data collection, frequency analysis and average index [32] were applied to discuss the balance between the development and protection of Yihe Mansions. 40.63\% of the respondents were the local living in the Yihe Conservation area, and $46.15 \%$ of them lived in this area over ten years. It means that the redeveloped area still supports a stable and mature community. The first question on the questionnaire is to immediately evaluate the development of the protection of this redeveloped area. The results show that $96.88 \%$ and $93.75 \%$ of respondents respectively thought to be positive in the protection and the development of Yihe Mansions. Respondents ranked that historical, cultural and aesthetic values were the top three significances of this area based on their experience and feeling, respectively occupying 93.75\% 81.26\% and $71.88 \%$ (see Fig. 8). This means that despite the function replacement and the resident relocation of this area, most respondents including the local community, believed that the main heritage values of the area have been conserved after the redevelopment. The respondents had been asked to evaluate the specific factors of the top three values of this area according to the individuals' ranking. Among the 32 valid questionnaires, the specific factors of historical values, cultural values and aesthetic values were evaluated by 30, 24 and 23 respondents respectively.

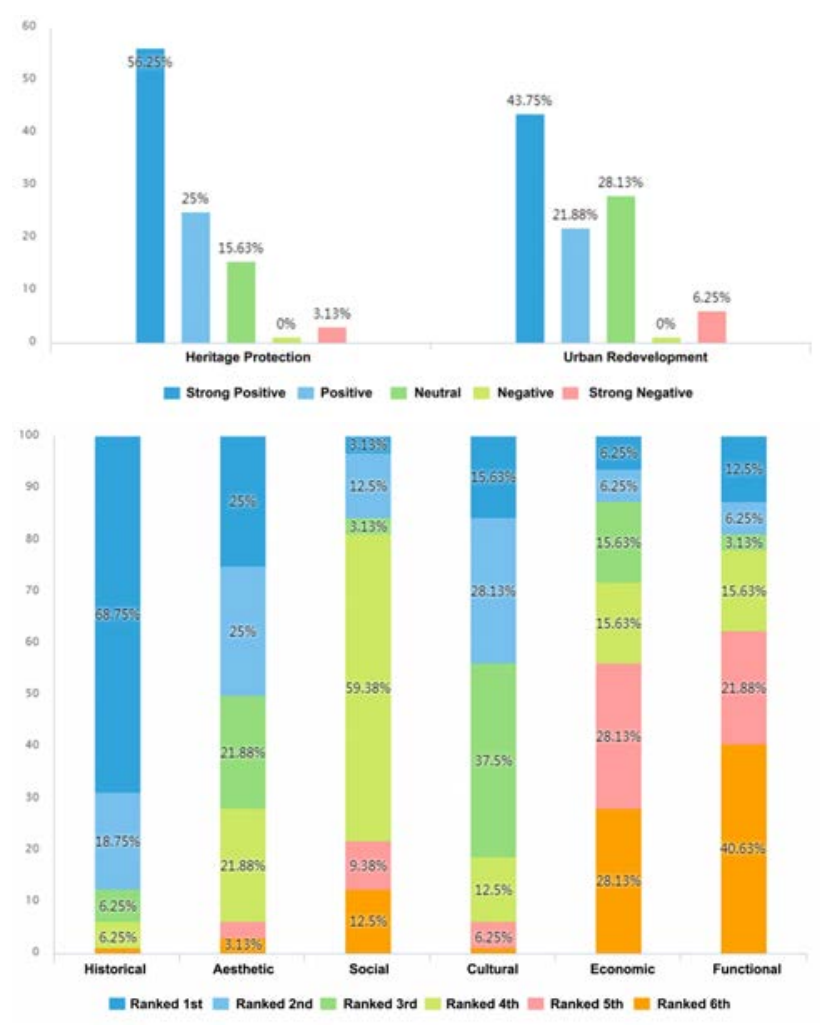

Figure 8: Evaluation of Protection and Development (up) and Ranking of Heritage. 
However, the final average index is calculated based on 32 respondents, resulting in the fact that many respondents gave positive comments on some specific factors, even with a low score. As illustrated in Table 1, most respondents agreed that this area as a human settlement demonstrated a representative pattern of urban development. They also believed that the associations of this area impacted an important period. Except for the disagreement on the intangible cultural heritage and cultural diversity of this area, respondents gave positive comments on the remaining factors. This is consistent with the fact that the main significance of this block is the residential area of senior officials who had been in a same social class with different political attitudes, thus there were not a compact community and cultural diversity formed in the Republic of China. Each respondent evaluated the heritage qualification including the authenticity and the integrity of this area currently. A commonly held view is that the authenticity and the integrity of this area have been positively inherited (See Table 2). In addition, it is obvious that the regeneration project of this block has improved the quality of buildings and environment and transformed the functions of this area, resulting in a number of economic returns to the government. As discussed previously, most end-users think that this area is an authentic heritage area with its fundamental values and integrity rather than a single commercial area. To sum up, this regeneration project is a government-led placemaking project, which not only improves the quality of the environment and revitalises its functions in terms of physical conditions, but also inherits main values and qualification of the heritage area creating a unique sense of place that end-users can perceive and reimage.

Table 1: Evaluation of specific factors of the top three values of Yihe Mansions by endusers. (Source: Author.)

\begin{tabular}{|c|c|c|c|c|c|c|c|c|c|}
\hline \multirow[b]{2}{*}{ Valuing Term } & \multirow[b]{2}{*}{ Criteria } & \multicolumn{6}{|c|}{ Frequency } & \multirow{2}{*}{$\begin{array}{l}\text { Average } \\
\text { index }\end{array}$} & \multirow{2}{*}{$\begin{array}{c}\text { Level of } \\
\text { agreemen }\end{array}$} \\
\hline & & $\begin{array}{l}\text { SA } \\
\text { (5) }\end{array}$ & $\begin{array}{c}\text { A } \\
(4)\end{array}$ & $\begin{array}{l}\mathrm{N} \\
\text { (3) }\end{array}$ & $\begin{array}{l}\mathrm{D} \\
(2)\end{array}$ & $\begin{array}{l}\text { SD } \\
\text { (1) }\end{array}$ & $\begin{array}{c}\text { Don't } \\
\text { Know (0) }\end{array}$ & & \\
\hline \multirow{4}{*}{$\begin{array}{l}\text { Historical } \\
\text { Values } \\
(30 \text { of } 32)\end{array}$} & $\begin{array}{l}\text { Human } \\
\text { Settlement } \\
\text { in Nature }\end{array}$ & 11 & 15 & 2 & 1 & 0 & 1 & 3.84375 & Agree \\
\hline & $\begin{array}{l}\text { Urban } \\
\text { Pattern }\end{array}$ & 16 & 9 & 2 & 2 & 0 & 1 & 3.9375 & Agree \\
\hline & Associations & 14 & 14 & 1 & 0 & 0 & 1 & 4.03125 & Agree \\
\hline & $\begin{array}{l}\text { Evolution of } \\
\text { Groups }\end{array}$ & 10 & 11 & 5 & 0 & 0 & 4 & 3.40625 & Neutral \\
\hline \multirow{4}{*}{$\begin{array}{l}\text { Cultural } \\
\text { Values and } \\
\text { Identity } \\
(24 \text { of } 32)\end{array}$} & $\begin{array}{l}\text { Intangible } \\
\text { Cultural } \\
\text { Heritage }\end{array}$ & 2 & 8 & 8 & 3 & 3 & 0 & 2.34375 & Disagree \\
\hline & $\begin{array}{l}\text { Cultural } \\
\text { Diversity }\end{array}$ & 4 & 5 & 8 & 2 & 4 & 1 & 2.25 & Disagree \\
\hline & Identity & 8 & 9 & 4 & 1 & 2 & 0 & 2.875 & Neutral \\
\hline & $\begin{array}{l}\text { Political } \\
\text { Ideology }\end{array}$ & 5 & 11 & 4 & 0 & 1 & 3 & 2.5625 & Neutral \\
\hline \multirow{3}{*}{$\begin{array}{l}\text { Aesthetic } \\
\text { Values } \\
\text { (23 of 32) }\end{array}$} & Preference & 12 & 8 & 3 & 0 & 0 & 0 & 3.15625 & Neutral \\
\hline & Elements & 10 & 10 & 1 & 1 & 0 & 1 & 2.96875 & Neutral \\
\hline & Style & 14 & 6 & 1 & 0 & 0 & 2 & 3.03125 & Neutral \\
\hline
\end{tabular}

SA: Strongly agree; A: Agree; N: Neutral; D: Disagree; SD: Strongly Disagree; Don’t Know: I don’t know. 
Table 2: Evaluation of authenticity and integrity of Yihe Mansions by end-users. (Source: Author.)

\begin{tabular}{|c|c|c|c|c|c|c|c|c|c|}
\hline \multirow[b]{2}{*}{$\begin{array}{l}\text { Valuing } \\
\text { Term }\end{array}$} & \multirow[b]{2}{*}{ Criteria } & \multicolumn{6}{|c|}{ Frequency } & \multirow[b]{2}{*}{$\begin{array}{l}\text { Average } \\
\text { index }\end{array}$} & \multirow[b]{2}{*}{$\begin{array}{l}\text { Level of } \\
\text { agreement }\end{array}$} \\
\hline & & $\begin{array}{l}\text { SA } \\
(5)\end{array}$ & $\begin{array}{l}\text { A } \\
(4)\end{array}$ & $\begin{array}{l}\mathrm{N} \\
(3)\end{array}$ & $\begin{array}{l}\mathrm{D} \\
(2)\end{array}$ & $\begin{array}{l}\mathrm{SD} \\
(1)\end{array}$ & $\begin{array}{c}\text { Don't } \\
\text { know } \\
(0)\end{array}$ & & \\
\hline \multirow{2}{*}{$\begin{array}{l}\text { Authenticity } \\
\text { (32 of } 32 \text { ) }\end{array}$} & $\begin{array}{c}\text { Credible } \\
\text { Information }\end{array}$ & 20 & 6 & 4 & 1 & 0 & 1 & 4.3125 & Agree \\
\hline & $\begin{array}{c}\text { Authentic } \\
\text { Values }\end{array}$ & 6 & 11 & 7 & 4 & 2 & 2 & 3.28125 & Neutral \\
\hline \multirow{2}{*}{$\begin{array}{l}\text { Integrity } \\
(32 \text { of } 32)\end{array}$} & Space & 13 & 10 & 5 & 2 & 1 & 1 & 3.90625 & Agree \\
\hline & Time/Process & 7 & 11 & 4 & 4 & 4 & 2 & 3.21875 & Neutral \\
\hline
\end{tabular}

SA: Strongly agree; A: Agree; N: Neutral; D: Disagree; SD: Strongly disagree; Don’t know: I don’t know.

\subsection{Dialogues between the government and the community}

In this case, the government acts as decision makers as well as project managers for the whole project. During the implementation of the regeneration project, the government released the zoning map to plan this area for residential, but this area eventually has been developed into a theme hotel due to the costly investment and the further management. Meanwhile, the government paid attention to the public agitation and found the lack of public facilities, thus proposing to reuse six celebrities' houses for the exhibition, supporting the local history and culture.

After project completion, the state-owned real estate company operates and manages this block on behalf of the government. A five-star hotel always has a strict security and visitor system, but one of the entrances to the hotel is adjacent to its neighbourhoods and open to the community all year round. There is a semi-public space like a small square next to this entrance, thus many old peoples with their grandchildren make their outdoor and social activities at this square, enhancing the neighbourliness even friendship in the community. And some elderly always stroll through the hotel as this area is a walkable, pedestrian-friendly, and car-free area with a high-quality landscape. The questionnaire results show that the locals occupy nearly half of all respondents and $53.85 \%$ of the local respondents visit this area for their chatting or strolling every day. Another observation worthy of note is that the locals obey some hotel's rules. For example, the outdoor tables and chairs are dedicated to hotel residents.

In short, there are positive dialogues between the government and the local community during the regeneration project. Particularly, the government proposed to provide the public facilities and improve the environment at the implementation phase, for saving the interests of the community and alleviate the resistance from them. After the project completion, the government adopts an open and friendly management model to the public, providing an area to meet the needs of the contemporary lifestyle and to support social activities of the community, ultimately forming a sense of belonging.

\section{CONCLUSION}

On the basis of the conflicts between China's rapid urbanisation and heritage protection in the metropolitan heritage areas, this study attempts to potentially and adaptively apply placemaking to the regeneration project of Chinese metropolitan heritage areas, balancing between the development and protection. Due to the land ownership in China, government 
support is inevitable even if placemaking advocates the community-led project. Yihe Mansions as an example, illustrates a government-led placemaking project which not only improves the physical conditions and revitalises the economy and functions of this area. And this conserves the important environment of the Republic of China and inherits the heritage values and qualification, ultimately attracting the public to understand the history and culture of this heritage area. The dialogue between the government and the community is an effective approach to bring the community voices to the fore and to guarantee the benefits of both stakeholders, with strong heritage values that uses placemaking concept to balance the development and protection to some extent, ultimately realising dynamic and sustainable development.

\section{REFERENCES}

[1] Buruma, I., China: New York or Singapore? The 21st century starts here. The New York Times Magazine. www.nytimes.com/1996/02/18/magazine/china-new-york-orsingapore-the-21st-century-starts-here.html. Accessed on: 23 Sep. 2018.

[2] Wu, W. \& Gaubatz, P.R., The Chinese City. Routledge: London, pp. 3-6, 2013.

[3] Ruan, Y., The protection process of international and Chinese cultural heritage. Tongji University Journal, Humanities and Social Science Section, 9(1), pp. 1-3, 1998.

[4] LV, Z., Conservation of Chinese cultural heritage during the 30 years past. Architectural Journal, 12, pp. 1-5, 2008.

[5] Cao, C., Protection of the historical and cultural heritages of China. China Ancient City, 3, pp. 27-33, 2009.

[6] Zhang, S., Review on the legal system of China cultural heritage protection. China Ancient City, 6, pp. 4-9, 2009.

[7] Ruan, Y. \& Sun, M., The study on some issues related to the conservation and planning for the historic streets and areas in China. City Planning Review, 25(10), pp. 25-32, 2001.

[8] Li, Z., A review of the research on historic area protection in China. Architecture and Culture, 9, pp. 78-81, 2016.

[9] Relph, E.C., Place and Placelessness. Pion: London, 1976.

[10] Schneekloth, L.H. \& Shibley, R.G., Placemaking: The Art and Practice of Building Communities, Wiley: New York, 1995.

[11] Liu, H., Place and place making in a globalizing world. Journal of Urban and Regional Planning, 1(3), pp. 215-224, 2008.

[12] Yang, G., Fang, J. \& Guan, Z., Place making of small-scale public space and reproduction of social capital in built-up areas in big cities. Shanghai Urban Planning Review, 1(2), pp. 1-7, 2017.

[13] Tuan, Y.F., Space and Place: The Perspective of Experience, University of Minnesota Press, 1977.

[14] Hutchison, R., Placemaking. Encyclopaedia of Urban Studies, SAGE: Thousand Oaks, pp. 600-603, 2010.

[15] Dovey, K., Urban design thinking. Planning News, 42(8), p. 20, 2016.

[16] Ministry of Housing and Urban-Rural Development of the People's Republic of China (MOHURD) \& General Administration of Quality Supervision, Inspection and Quarantine of the People's Republic of China. Code of Conservation Planning for Historic Cities, China Architecture \& Building Press: Beijing, 2005.

[17] Zhang, S., An Introduction to Integrated Conservation: A Way for the Protection of Cultural Heritage and Historic Environment, Tongji University Press: Shanghai, 2008. 
[18] Lin, Y., The Theory of Heritage Protection in Chinese Architecture, China Architecture \& Building Press: Beijing, 2012.

[19] ICOMOS China, Principles for the conservation of heritage sites in China. www.getty.edu/conservation/publications_resources/pdf_publications/china_ principles_revised_2015.html. Accessed on: 23 Mar. 2019.

[20] ICOMOS, The Paris Declaration on heritage as a driver of development, Adopted at Paris. $\quad$ www.icomos.org/Paris2011/GA2011_Declaration_de_Paris_EN_ 20120109.pdf. Accessed on: 23 Oct. 2018.

[21] Norberg-Schulz, C., Genius Loci: Towards a Phenomenology of Architecture, Rizzoli: New York, 1980.

[22] Grabow, S., Principles and practice of community placemaking. https://blogs.ces.uwex.edu/community/files/2014/08/Placemaking-DocumentPrinciples-and-Practice-of-Community-Placemaking-updated-5-14-14.pdf. Accessed on: 23 Oct. 2018.

[23] Thomas, D., Placemaking: An Urban Design Methodology, Routledge: New York, 2016.

[24] Urban Design London, The Design Companion for Planning and Placemaking, RIBA Publishing: London, 2018.

[25] Project for Public Space, What is placemaking? www.pps.org/article/what-isplacemaking\#comments. Accessed on: 23 Oct. 2018.

[26] UNESCO, Operational guidelines for the implementation of the world heritage convention. https://whc.unesco.org/en/guidelines. Accessed on: 23 Oct. 2018.

[27] State Council of People's Republic of China, Regulation on the Protection of Historic Cities, Towns and Villages, 2008.

[28] UNESCO, Policy document for the integration of a sustainable development perspective into the processes of the World Heritage Convention. https://whc.unesco.org/en/sustainabledevelopment. Accessed on: 23 Oct. 2018.

[29] Silberberg, S., Lorah, K., Disbrow, R. \& Muessig, A., Places in the Making: How Placemaking Builds Places and Communities. Massachusetts Institute of Technology: Boston, 2013.

[30] Project for Public Space, Placemaking meets preservation. www.pps.org/blog/placemaking-meets-preservation. Accessed on: 23 Oct. 2018.

[31] Nanjing Urban Planning Bureau, Conservation Planning of the Historical and Cultural Blocks, 2013.

[32] Bakri, A.F., Ibrahim, N., Ahmad, S.S. \& Zaman, N.Q., Public perception on the cultural significance of heritage buildings in Kuala Lumpur. Proceedings of ABRA International Conference on Quality of Life, pp. 294-302, 2015. 